\title{
Management and Operational Issues of Animation Services in Resort and All-inclusive Hotels: Evidence from Greece
}

\author{
Prof. Marios D. Sotiriadis \\ Visiting Professor, University of South Africa, Department of Transport \\ Economics, Logistics \& Tourism, Pretoria, South Africa \\ Email: sotirm@unisa.ac.za / sotermarios@gmail.com
}

\section{Doi:10.5901/mjss.2014.v5n20p692}

\begin{abstract}
Literature suggests that animation and events contribute to enhancing visitor experiences. Animation is the process of programming interpretive features and/or events that make the place come alive with sensory stimulation and appealing atmosphere. In sea-and-sun destinations animation services became a constituent part in hotels. These services constitute a significant function in resorts considered as being a business asset capable to offer direct and indirect benefits and to attain competitive advantage. The aim of this study is to explore management and operational issues related to the successful offering of animation services. A literature review is performed in the first section. This is followed by a synoptic presentation of international experience. The main part of the study is dedicated to four case studies of Greek resort and all-inclusive hotels; focusing on the main management and operational issues. The paper concludes by identifying the factors crucial to the successful offering of animation services. Finally, it provides recommendations in order to improve performance.
\end{abstract}

Keywords: Animation and entertainment services, Hotels, Management, Operations, Greece.

\section{Introduction}

Literature suggests that animation and events contribute to enhancing visitor experiences (e.g. Bowdin, Allen, O'Toole, Harris, \& McDonnell, 2011; Getz, 2005). Resorts, museums, heritage sites, and theme parks all develop programs of events. Attractions and facilities all over the world have realised the advantages of animation. In this regard, hotel and other tourism related businesses often offer similar animation programs and events to render their guests' experience more enjoyable. Animation / recreational services have become a constituent part of the hotel businesses offering, aiming at providing an integrated holidays experience. Hence, it might be stressed that hotels have 'borrowed' some ideas from entertainment methods and techniques implemented since 1970's by holiday clubs and all-inclusive resorts; the Club Mediterranée (Club Med) being considered as the most representative example.

The term 'hotel animation' is frequently used to describe recreational services offered by resorts in sun-and-sea destinations (Mikulic \& Prebezac, 2011). It is the special function that encompasses every activity offering movement, joy, leisure and spectacle, such as games, sports, shows, events, etc (Laloumis, 2000). These activities are mainly classified into two areas: Performing Arts and Sports. Their aim is twofold: (i) to meet the vacationers' needs for fun and entertainment; (ii) to provide them with opportunities for better social contact and communication. Obviously, the attainment of business objectives is function of adequate management, facilities, and human resources. The aim of this study is to explore issues related to the successful offering of entertainment services. First section briefly analyzes management and operational issues. In the next section a review literature review is performed. The main part of the study is dedicated to four case studies of Greek resort hotels.

\section{Animation and Entertainment Services}

Animation services could be defined as being the hotel's special function that offers guests the opportunity and the means to communicate and interact with other tourists, to create, to satisfy and finally to entertain themselves during their holidays (Glinia, Lytras, \& Maras, 2004; Laloumis, 2000). According to Costa, et al. (2004) the term originates from club resorts in the Mediterranean region, that provide organized sporting activities for tourists who desire active recreation. $\mathrm{A}$ broader definition of animation encompasses a range of other recreational activities provided for hotel guests, such as games and various events (Bowdin et al., 2011). In tourism the concept 'animation' generally means motivation to perform activities, relaxing and social contact. It encompasses every activity offering movement, joy and leisure. 
The aim of animation function is twofold (Laloumis, 2000; Lytras, 2002; Glinia et al., 2004): (i) to meet the vacationers' needs for fun and sports; (ii) to provide them with opportunities for better social contact, interaction and communication. The main criteria of classifying hotel animation services are three (Laloumis, 2000; Lytras, 2002): (i) age group, (ii) location of activities (indoors or outdoors), and (iii) the degree of involvement of participants (passive or active). The first criterion encompasses a marketing component. According to this classification, there are two main market segments (Sotiriadis, 2005; Mikulic \& Prebezac, 2011): (i) Children: Activities and games at the beach, playground and other kids facilities, various lessons/tuition, dance, etc. (ii) Adults: Gym, fitness and aerobics, sports, entertainment games, and other events. Hotel businesses implement animation programs to increase market profile and attract repeat clientele; hence, from a business perspective, the main objectives in operating such services are: (i) to offer a wide spectrum of opportunities to their guests; (ii) to improve their reputation; and (iii) to gain a competitive advantage (Laloumis, 2000; Sotiriadis, 2005). Obviously the attainment of business objectives and customer satisfaction are function of three determining factors: facilities, human resources, and appropriate planning and management. These issues are the topic of our study. Before going on, it is worth analyzing this function from a management and operational perspective. The hotel's benefits resulting by animation function are mainly twofold: (i) Direct benefits resulting by paid services, such as sports tuition, baby sitting, children's special menu, and special events. The most significant benefits are food and beverage expenses during entertainment activities. (ii) Indirect benefits: build up a competitive advantage and better market positioning, customer loyalty, attract new customers. It is estimated that indirect benefits are more significant (Laloumis, 2003; Glinia et al., 2004).

It could be stressed that the most important managerial and operational issues are: planning, facilities, clientele, promotion, staff, and financial matters (Laloumis, 2000; Lytras, 2002; Sotiriadis 2005). The crucial pillar of any animation program is adequate planning, taking into consideration five issues, namely: guests, amenities, staff, promotion, and financial. Firstly, one key issue is the hotel's clientele features: nationality; clientele segment (families with kids, youths, and adults); the arrival day and duration of stay; and a balanced distribution and frequency of activities. Hotel management has to take special care of guests' needs. It should be noted that such programs are, besides for the children participating in them, also very attractive for their parents who wish to spend some time on their own while on vacation with their children (Mikulic \& Prebezac, 2011). Secondly, hotel management has to use the maximum of available indoors and outdoors amenities, make the hotel infrastructure profitable. Thirdly, a crucial parameter is staff's volume and composition; it has been suggested that proportion could be around one animator per 100-150 guests (Laloumis, 2000). However, the determining factors are the variety of activities, age groups and nationalities. Fourthly, the entertainment services promotion is an essential prerequisite for the program's success. At this end some techniques and methods are useful: animation desk at the lounge; welcome and information meetings with animation team; information board; leaflets in the rooms; personal contact.

Last but not least are financial matters. It is estimated that three issues are to be carefully considered; i.e. (i) Extra charge: Generally, the majority of entertainment activities are offered to guests free of charge, they constitute a part of the services package. However, hotel management might charge clients for some services; it is a matter of business option. (ii) Animation expenses are composed of investments (amenities), equipment and operating expenses; wages being the most significant. Staff expenses (wages, catering and transport) are corresponding to about $90 \%$ of function's total expenses (Sotiriadis 2005). Generally, it has been observed that there is reluctance on behalf of resorts to operate animation function. This attitude might be due to three factors: (i) lack of significant direct benefits resulted by amenities investment; (ii) relatively high additional operating expenses; and (iii) difficulty of recruiting properly skilled staff.

From the above analysis, a number of management questions are raised. Resort and all-inclusive hotels have to make some essential policy decisions, namely: (i) Is it feasible to offer animation services to clientele? (ii) If the answer is positive, what kind of activities should be provided? Should they offer a unique animation program for all guests (onelanguage) or a distinct program for each nationality? (iii) What would be the planning method and operational mode? The function must be operated by resort's management, or it would be completely or partially outsourced? (iv) Which method of customer feedback should be adopted and implemented? The management options are determined by the following crucial parameters: resort's capacity, clientele, and business general competitive strategy. Eventually resort management can decide to, or not to operate the animation function. Nevertheless, the offering of entertainment services could be imposed by market conditions and business environment. It is wiser to properly plan this function instead of been forced to implement it by external factors (Sotiriadis 2005).

\section{Literature Review and International Experience}

Despite the importance of this special function, research on animation and entertainment offering is very scarce. The 
issues of all-inclusive vacations and animation have not been explored by literature. Only few studies have investigated this topic, mainly from an operational perspective (e.g. Costa et al., 2004). From a sociological perspective, Lytras (2002) made use of critical theory to analyze all-inclusive vacations as a sociological phenomenon. This type of holiday should protect the consumer from anything to upset previous notions of a place or what a vacation should be about. The allinclusive vacation keeps consumers within one kind of consciousness that is the one known at home.

Other related literature (e.g. Glinia \& Laloumis, 1999; Torkildson, 2004), argues that vacationers are mainly motivated by health and social contact for leisure activities, as well as for hotel animation. Furthermore, it is estimated that sporting activities in hotel settings must have an entertaining and social character (Laloumis, 2000). The active participation of guests into entertainment activities leads to more significant psychological outcomes compared to a passive one. That is the reason why animation function efforts are mainly oriented to organize activities in which guests are actively involved (Lytras, 1999; Laloumis, 2000). In this regard, the animators' role is crucial in two fields: make clients feel comfortable, participate, create and ensure groups dynamics (Laloumis, 2003). Other scholars (e.g. Getz, 2005) have investigated the topic of events and festivals. It is estimated that events are contributing to create a more attractive environment; helping attract and retain visitors; enriching the vacations' experience. Events produced for the explicit purpose of being 'consumed' by tourists are common. Getz (2005) estimates that, from consumer or audience perspective, an event is an opportunity for leisure, social or cultural experience outside the normal range of choices or beyond everyday experience. These events must be of interest and attractive to potential consumers, so from a marketing perspective the product must be matched to carefully defined target segments.

Finally, a very recent study was performed by Mikulic \& Prebezac (2011) on perceptions and satisfaction from the consumers' perspective. The primary objective of this study was to explore the key-drivers of customer experience with animation programs typically offered by resorts in the Mediterranean. This study explores the determinants of guest satisfaction and dissatisfaction with recreational, using the case of a large Croatian hotel chain. Their findings indicate several significant asymmetries in the formation of overall guest satisfaction, as well as differences according to the type of accommodation, and selected demographic characteristics (gender and age) of resorts guests. Authors argue that two of the most critical success factors: an attractive mix of activities and a professional staff (Mikulic \& Prebezac, 2011). Apparently, current knowledge in this field is either incomplete or shallow. The literature review reveals that there is a knowledge gap relating to the management and operational issues of animation services from a business perspective. In this regard, the aim of present study is to contribute to the successful planning, management and operation of animation programs in resort and all-inclusive hotels.

It is believed that a brief presentation and analysis of some issues drawn on examples resulting from international experience would be useful. A resort is usually a hotel accommodation used for relaxation or recreation, attracting visitors for holidays; that's why resorts provide an array of amenities which typically includes entertainment activities (Glinia, et al. 2004; Timothy \& Teye, 2009). A resort generally contains, in and of itself, the necessary guest attraction capabilities. An all-inclusive resort is a resort that, besides providing all of the common amenities of a resort, charges a fixed price that includes most or all items. By definition, an all-inclusive resort is a holiday resort that includes all meals and most alcoholic drinks included in one, upfront price (Sotiriadis, 2005). All-inclusive resorts can provide a great vacation experience without any pre-trip stress to holidaymakers. Many also offer a selection of sports and other activities included in the price as well. The all-inclusive model originated in the Club Med (CM) resorts. Since CM established the 'allinclusive' resort in the '50s, it has become one of the most popular types of resorts for millions of travellers. Some allinclusive resorts are designed for specific vacation interests to cater for adults (Nagle, 1999). Resorts are found all over the world, they are especially prevalent in the Caribbean and the Mediterranean. In recent years, the number of resorts offering 'all-inclusive' amenities in the Mediterranean has increased (Lytras, 2002; Laloumis, 2003; Weiermair \& Mathies, 2004). All over the Mediterranean, resorts offer entertainment and recreational activities (Laloumis, 2003; Sotiriadis, 2005). The most notable trends in business environment are professionalism and outsourcing. Professional animation teams (in-house or outsourced) are presenting and performing activities and shows in the daytime and night. They provide, amongst others, experienced and skilled staff, animation program. Concerning outsourcing, it is worth stressing that four and five star resorts are outsourcing animation function and companies have been established aiming to provide related services and recruit staff for animation. Moreover some specialized consulting companies (e.g. Hotel consulting, 2013) are active in the field and offer their knowhow and expertise in motivating guests of all ages into getting involved in some entertaining fun.

The best-known and the first all-inclusive resort company is Club Med (CM), a French corporation of vacation resorts found all over the world. Its staff is 20,333 employees and its revenue $€ 1,360$ billion (Club Med, 2013). In 2002 a new strategy was announced returning to a focus on the holiday villages and for upmarket vacationers. From 2001 on, the resort company worked to rebrand itself as upscale and family-oriented. Clientele today is affluent and 70\% Family, 
20\% Couples, 10\% Singles. In 2004, the hotel group Accor became the largest shareholder, but it sold most of its stake in 2006, announcing that it wished to refocus on its core businesses. Its main competitors include SuperClubs, Carnival Corporation, Sol Meliá, and Sandals Hotels. Each resort provides a list of services and activities in one single package. This includes lodging, food, use of facilities, sports activities, games, and shows. CM originally pioneered the 'allinclusive' concept, but it has expanded to include a number of variants, some of which are not so all-inclusive. As of November 2010 the resort company operates eighty villages in Europe, Africa, North America, the Caribbean, South America, Asia, Australia, Indian Ocean and Pacific Ocean.

\section{Empirical Study: Greek Resort Hotels}

\subsection{Study: Methodology and Resorts}

The study employed a collective case study methodology. A case study is an empirical inquiry that investigates a contemporary phenomenon within its real-life context. Relevant data is gathered through the use of multiple sources including observations, interviews and narrative reports (Yin, 2003). The objective of this study was to gain a better knowledge of managerial and operational issues of resorts' animation and entertainment services. It is based primarily on documentary evidence derived from a number of sources, including soft and hard copies of informational report and promotional material of resort businesses. Moreover data was collected through semi-structured interviews with four managers conducted in May 2013.

The research explored four Greek seaside resorts, the rationale being that this should produce insights into animation's managerial issues, such as organization, program, and human resources. Hopefully the four cases studies discussed in this paper will contribute to a better understanding and may even provide a platform for further research. The first resort (MR) constitutes a very good choice for active adults and families. It provides excellent water sports, separate adult-only facilities and a wide range of accommodation. The second one (NB) looks like being a very good choice for sociable club experience. The third one $(A B)$ is a long established resort, located on very nice beach. The last one (KB) has spacious amenities and offers 'all-inclusive' packages. The investigated resorts' main features are shown in Table 1.

Table 1: Investigated Greek seaside resorts - features

\begin{tabular}{|l|l|l|l|l|}
\hline Features & Hotel resort MR & Hotel resort NB & Hotel resort AB \\
\hline Location (Island) & Rhodes & Crete & Crete & Hotel resort KB \\
\hline Management status / mode & Unit of hotel chain & Independent unit /All inclusive & Unit of a hotel group & Unit of a hotel group \\
\hline Class (in stars) & 4 & 4 & 4 & 4 \\
\hline Capacity (in beds) & 580 & 480 & 350 & 465 \\
\hline $\begin{array}{l}\text { Clientele (mainly families\& } \\
\text { couples) }\end{array}$ & $\begin{array}{l}\text { Scandinavian, German, } \\
\text { Dutch }\end{array}$ & German, Dutch, British & French, German, Dutch & German, Scandinavian \\
\hline Animation Team & $\begin{array}{l}\text { In-house team of six } \\
\text { persons }\end{array}$ & Team of seven members & $\begin{array}{l}\text { A multilingual team of nine } \\
\text { persons }\end{array}$ & $\begin{array}{l}\text { A multilingual team of six } \\
\text { members }\end{array}$ \\
\hline $\begin{array}{l}\text { Animation Entertainment and } \\
\text { Sports Offering/ Services }\end{array}$ & $\begin{array}{l}\text { Full program of activities } \\
\text { and evening animation. }\end{array}$ & $\begin{array}{l}\text { An assortment of choices for } \\
\text { entertainment \& sport activities. }\end{array}$ & $\begin{array}{l}\text { Various activities and } \\
\text { programs, day and evening }\end{array}$ & $\begin{array}{l}\text { Daily animation and } \\
\text { entertainment activities }\end{array}$ \\
\hline
\end{tabular}

It is worth pointing out that all hotels offer different levels of 'inclusiveness' depending on guests' interests and needs.

\subsection{Study's Findings and Discussion}

The main study's findings - animation program, characteristics and services - are presented hereafter. Usually the resort's animation program is on a weekly basis due to holidaymakers' stay duration, lasting one to two weeks. Into Tables 2 and 3 is shown a synoptic image of animation services for adults, drawn upon offering of four resorts under study. This presentation allows indicating activities and most important issues of this special function from a management and operational perspective. 
Table 2: Daily animation program - activities

\begin{tabular}{|c|l|l|l|}
\hline Daytime Day & Morning 9.30 to 13.00 & Afternoon 14.30 to19.30 & Night 20.30 to 02.00 \\
\hline Monday & $\begin{array}{l}\text { Footing / Gym / Beach volley / Aqua Jogging } \\
\text { /Greek Lesson / Aperitif game }\end{array}$ & $\begin{array}{l}\text { Tennis tuition/Water Polo / Coffee game /Beach } \\
\text { volley / Aerobic/Aperitif game }\end{array}$ & $\begin{array}{l}\text { Mini disco (kids)/ Music / Show } \\
\text { (cabaret)/ Club dance }\end{array}$ \\
\hline Tuesday & $\begin{array}{l}\text { Footing / Gym / Beach volley /Tournament } \\
\text { Billiard / Walk }\end{array}$ & $\begin{array}{l}\text { Tennis / Football/ Beach soccer / Aerobic/ Aperitif } \\
\text { game }\end{array}$ & $\begin{array}{l}\text { Mini disco (kids) / Jazz/ Show } \\
\text { (theatre / comedy) / Club dance }\end{array}$ \\
\hline Wednesday & $\begin{array}{l}\text { Footing / Aqua Gym / Beach volley/ } \\
\text { Tournament - Table tennis / Greek Lesson }\end{array}$ & $\begin{array}{l}\text { Surfing tuition/ Frisbee / Coffee game/ } \\
\text { Badminton/ Aerobic/Aperitif game }\end{array}$ & $\begin{array}{l}\text { Mini disco (kids) /Music Latin/ } \\
\text { Show / Club dance }\end{array}$ \\
\hline Thursday & $\begin{array}{l}\text { Footing / Gym / Beach volley / } \\
\text { Tournament - Squash/ Cooking Lesson }\end{array}$ & $\begin{array}{l}\text { Mini Golf / Football / Coffee game/ Beach volley / } \\
\text { Aerobic/Aperitif game }\end{array}$ & $\begin{array}{l}\text { Mini disco (kids)/Music retro/ } \\
\text { Show/Club dance }\end{array}$ \\
\hline Friday & $\begin{array}{l}\text { Footing / Aqua Gym / Beach volley/ } \\
\text { Tournament - Billiard Hotel Walk }\end{array}$ & $\begin{array}{l}\text { Fitness / Backgammon tuition/ Coffee game/ Beach } \\
\text { soccer / Aperitif game }\end{array}$ & $\begin{array}{l}\text { Mini disco (kids)/Dance contest/ } \\
\text { Show (bingo)/ Club dance }\end{array}$ \\
\hline Saturday & $\begin{array}{l}\text { Footing / Aqua Gym / Beach volley / } \\
\text { Tournament - Darts /Greek Lesson }\end{array}$ & $\begin{array}{l}\text { Traditional dances tuition/ Darts / Coffee game/ } \\
\text { Beach volley /Aperitif game }\end{array}$ & $\begin{array}{l}\text { Mini disco (kids)/ Jazz/ Show } \\
\text { (pantomime)/ Club dance }\end{array}$ \\
\hline Sunday & $\begin{array}{l}\text { Aqua Gym / Beach volley / Tournament - } \\
\text { Backgammon /Aperitif game. }\end{array}$ & $\begin{array}{l}\text { Water Polo / Coffee game/ Basketball/ Beach soccer } \\
\text { /Aerobic/ Aperitif game }\end{array}$ & $\begin{array}{l}\text { Mini disco/ Greek dance tuition/ } \\
\text { Show/Club dance }\end{array}$ \\
\hline
\end{tabular}

Note: A program for children is provided, generally a six-day, the seventh day (usually Saturday) being to get with family (see Table 3)

Table 3: Animation services: a summary

\begin{tabular}{|c|c|c|c|c|}
\hline Animation Treats & Hotel resort MR & Hotel resort NB & Hotel resort $A B$ & Hotel resort KB \\
\hline $\begin{array}{l}\text { 1. Ambience / } \\
\text { Atmosphere }\end{array}$ & Family ambience & $\begin{array}{l}\text { Family holidays, offering special } \\
\text { fun for children }\end{array}$ & $\begin{array}{l}\text { Family fun programs, friendly } \\
\text { amenities }\end{array}$ & A festive ambiance and sport \\
\hline $\begin{array}{l}\text { 2. Outsourcing: } \\
\text { Associate / External } \\
\text { partners }\end{array}$ & Water sports centre & $\begin{array}{l}\text { Water sports and Scuba diving } \\
\text { centre }\end{array}$ & Golf Club associate partner & Water sports centre \\
\hline $\begin{array}{l}\text { 3. Daytime Activities } \\
\text { 3.1. Land \& outdoors } \\
\text { activities }\end{array}$ & $\begin{array}{l}\text { Gym, French boules, Aerobics, } \\
\text { Tennis, Beach volley. }\end{array}$ & $\begin{array}{l}\text { Bike, Tennis Archery, Aerobic, } \\
\text { Basketball, Beach volley, Mini } \\
\text { soccer }\end{array}$ & $\begin{array}{l}\text { Gym, Aerobics, Board games, } \\
\text { Tennis, Mountain bike, Beach volley }\end{array}$ & $\begin{array}{l}\text { Archery, Aerobic, Tennis } \\
\text { Basketball, Beach volley, } \\
\text { Mini football 5X5 }\end{array}$ \\
\hline 3.2. Water sports & $\begin{array}{l}\text { Aqua aerobics, Pool games and } \\
\text { competitions, Water polo, Aqua } \\
\text { fun }\end{array}$ & $\begin{array}{l}\text { Aqua aerobics, Beach games, } \\
\text { Canoes Scuba Diving, Pedal } \\
\text { boats, Surfing, Water ski. }\end{array}$ & $\begin{array}{l}\text { Water gymnastics, Water polo, } \\
\text { Windsurfing, Waterskiing, } \\
\text { Parasailing, Pedal boats, Canoes }\end{array}$ & $\begin{array}{l}\text { Aqua aerobic, Pool games, } \\
\text { Pedal boats, Canoes, } \\
\text { Surfing, Snorkelling, Water } \\
\text { ski }\end{array}$ \\
\hline $\begin{array}{l}\text { 3.3. Indoors \& Other } \\
\text { activities }\end{array}$ & $\begin{array}{l}\text { Darts competition, Table tennis, } \\
\text { Squash }\end{array}$ & $\begin{array}{l}\text { Billiards, Table tennis, Board } \\
\text { games, Darts Fitness gym. }\end{array}$ & $\begin{array}{l}\text { Fitness gym, Table Tennis, Atelier } \\
\text { (studio courses) }\end{array}$ & $\begin{array}{l}\text { Table tennis, Board games, } \\
\text { Darts, Fitness gym }\end{array}$ \\
\hline $\begin{array}{l}\text { 4. Evening } \\
\text { entertainment }\end{array}$ & $\begin{array}{l}\text { Live music, Live shows \& } \\
\text { dancing, Beach party, Wine } \\
\text { tasting, Bar games, Theme } \\
\text { nights. }\end{array}$ & $\begin{array}{l}\text { Show, Greek evening (live music } \\
\text { and folklore dance), Dance } \\
\text { evening, Live music, Piano } \\
\text { nights }\end{array}$ & $\begin{array}{l}\text { Folklore dance show, Greek } \\
\text { evening (live show), Piano nights, } \\
\text { Musicals, Sketches. }\end{array}$ & $\begin{array}{l}\text { Greek evening (live music), } \\
\text { Folklore dance show, Disco } \\
\text { night, Live concert. }\end{array}$ \\
\hline $\begin{array}{l}\text { 5. Special Kids } \\
\text { Program / Activities } \\
\text { (Mini club) }\end{array}$ & $\begin{array}{l}\text { Arts \& crafts, Movie, Pirate day, } \\
\text { Card making, Painting, Mini } \\
\text { Olympics, Disco Wishing tree }\end{array}$ & $\begin{array}{l}\text { Mini Club, Tennis lessons, } \\
\text { Disco, Water-Skiing tuition, } \\
\text { Babysitting, Creative activities }\end{array}$ & \begin{tabular}{|l|} 
Painting, Beach \& poll games, \\
Theatre, Swimming tuition, Board \\
games, Party, Disco show, Walking
\end{tabular} & $\begin{array}{l}\text { Daily animation program } \\
\text { Mini club (children } 4 \text { to } 12 \\
\text { years) five hours per day }\end{array}$ \\
\hline $\begin{array}{l}\text { Miscellaneous and } \\
\text { Other Services } \\
\end{array}$ & N/A & $\mathrm{N} / \mathrm{A}$ & $\begin{array}{l}\text { Greek cooking lessons, } \\
\text { Environmental activities \& tours }\end{array}$ & $\begin{array}{l}\text { Italian cooking lessons with } \\
\text { an extra charge }\end{array}$ \\
\hline \begin{tabular}{|l} 
Offered as all- \\
inclusive package
\end{tabular} & Yes & Yes & Yes & Yes \\
\hline
\end{tabular}

Source: Information retrieved from interviews and resorts' websites.

Based on above tables we could point out the main managerial practices and operational issues of animation services provided by resorts under study. As for the daily program, it is estimated that activities are planned taking seriously into account all crucial factors: market, clientele's interests and needs; available facilities and amenities. Obviously there is flexibility, the program being adaptable to weather conditions. Concerning cultural / creative activities and events, as it can be seen from Table 3, three resorts offer Greek evening (live music and folklore dance), only one resort offers Greek dance tuition; and only one provides the opportunity for Greek cooking lessons and environmental activities.

With regard to amenities, it seems that all four resorts have all necessary entertainment and sports facilities; (i) indoors: bars, disco, mini-club, table tennis, billiards, squash, badminton ground, disco, play room; (ii) outdoors: roof garden, beach bar, swimming pools, pool bar, tennis ground, mini golf, sports grounds. Concerning children's program, all resorts are providing children activities with special care, aiming at rendering parents free of obligations and worries in such a way as to participate in the various activities. They provide child care contributing to increased clientele and income at food and beverage departments. Financial issues: It is worth stressing that most of activities are free of charge, 
in other words are included in the accommodation agreement terms as a package. However, services are charged in the following cases: (i) sports tuition; (ii) use of mechanical means, such as water ski, scuba diving, etc.; the aim being to avoid overcrowding and to partly cover operating expenses; (iii) live music and theme nights. Usually, Greek resorts charge sports tuition, children' special meal and special evenings.

As for communication and promotion, sales promotion techniques are mainly consisting of in-house promotion and the resorts' website. The animation program is presented on information boards in the lounge, as well as in the guests' rooms. The main tool is information meetings held by animation staff. All resorts have 'happy hour' and offer a drink to games' winners. All managers estimate that a customer feedback is needed. The questionnaire's findings would permit to identify possible deficiencies and shortcomings. A questionnaire is the sole tool for evaluating entertainment services. They use a general questionnaire (for all resort's services and facilities), including service (staff's efficiency); it encompasses a section dedicated to animation facilities and services. This tool enhances resort management to evaluate holidaymakers' satisfaction degree and to determine possible deficiencies. According to business performance/outcomes and customer feedback's findings, all resorts' managers estimate that guests' participation rate in various entertainment activities is very high; varying $80 \%$ to $90 \%$ of adult guests.

All four resort managers believe the crucial factor is the animation staff considerably contributing to successful provision of such services, confirming findings from previous studies (Mikulic \& Prebezac, 2011). Further, they estimate that their business sufficiently takes advantage from all entertainment facilities. They have incorporated animation function into business plan, aiming at all direct and indirect benefits. They consider that the main business outcomes are: clientele increase, improved reputation, clientele loyalty, word-to-mouth recommendation, and achieving competitive advantage. These findings confirm the results indicated by previous studies (Costa et al. 2004; Glinia \& Laloumis, 1999). On the other hand, they estimate that the main difficulties to handle are high operating expenses (mainly wages) and the difficulty to recruit competent staff. Therefore, they estimate that outsourcing is a wise business option. Since growing interest in active recreation and diverse entertainment is a persistent trend in the vacation industry (Bowdin et al., 2011), resort managers should, however, treat animation programs as an important service component with large potentials to enhance the overall resort experience, as suggested by Mikulic \& Prebezac (2011).

\section{Conclusion, Recommendations and Study's Limitations}

The entertainment services constitute a significant function in resorts considered as being a business asset capable to offer direct and indirect benefits. It seems that many resorts realized this opportunity, and adopted and implemented tools used by vacation clubs. The study of four Greek resorts highlighted some managerial and operational issues and practices related to animation services. The study has shown that this function could have a significant contribution to attain business strategic aims, in the fields of management and marketing.

The study's conclusions are twofold. Firstly, there are management implications. One crucial issue and a major challenge suggested by related research have been confirmed. There is a requirement for efficient management; in other words, use appropriate approach and tools. This approach is imperative in order to consistently ensure high quality services and to appeal to ever more demanding customers. The management challenge is to create a customer focus driven by competent staff. Additionally, the study identified those factors which are considered crucial for successful offering of animation services. Main operational factors of animation programs affecting the efficient and successful offering are four: (i) Program: variety of activities, attractiveness, quality of performance. (ii) Staff: skills and competence. (iii) Facilities and equipment: quality and variety. (iv) Ambience: atmosphere, participants, and location. It is estimated that a well planned / balanced animation program and a competent animation team constitute the centrepiece for successful operation. Therefore, staff must possess the needed capabilities and skills, as well as knowledge and expertise. Other influencing factors are amenities and related equipment. Another important parameter is children's program and care. The use of appropriate sales promotion techniques and adequate tool for evaluating animation services are two issues requiring special attention. All these factors must be carefully considered in order to offer high quality service and a memorable experience.

Secondly, this study demonstrated that cultural and creative activities are not a priority for Greek resorts business. In other words, the research findings showed that resorts management don't pay attention to local culture and production. It is our conviction that this is a serious deficiency. One idea / suggestion could be the organisation of events jointly with other destination stakeholders. The positive contribution of these events has been stressed by related research (e.g. Bowdin et al., 2011; Getz, 2005; Hall \& Sharples, 2008). These events must be provided in such a way that commercial goals are made to fit cultural goals, stimulate both emotional and intellectual curiosity; offer culturally genuine goods and performances, such as local foods, dances, and crafts. 
The study's findings may serve as guidelines for hotel managers in planning, managing, implementing and evaluating appropriate animation programs. However, it must be stressed that study encompasses some limitations. It is an exploratory research, the method used is a case study and further testing with other cases would confirm conclusions and determining factors. Further investigation is needed; more studies must be performed in similar tourism destinations in order to gain a deeper understanding.

\section{References}

Bowdin, G., Allen, J., O'Toole, W., Harris, R. \& McDonnell, I. (2011). Events management. (3rd ed.). Oxford: Elsevier ButterworthHeinemann.

Club Med (2013). Corporate official website. Available: http://www.clubmed.com. (February 18, 2013)

Costa, G., Glinia, E., Goudas, M., \& Antoniou, P. (2004). Recreational services in resort hotels: customer satisfaction aspects. Journal of Sport Tourism, 9(2), 117-126.

Getz, D. (2005). Event management and event tourism. (2nded.). New York: Cognizant Communications Corporation.

Glinia, E., \& Laloumis, D. (1999). Club hotel animation and animation in Greek hotel operations: areas of contrasts. International Conference on Sport Management in the Next Millennium, European Association for Sport Management, Athens, Greece, September 16-19.

Glinia, E., Lytras, P., \& Maras, D. (2004). Animation: guests' entertainment and sporting activities. Athens: Interbooks.

Hall, M., \& Sharples, L. (2008). Food and wine festivals and events around the world. Oxford: Elsevier.

Hotel Consulting (2013). Corporate official website. Available: http://www.hotelconsulting.gr (March 10, 2013)

Laloumis, D. (2000). Hotel animation and sports. Athens: Stamoulis Publications.

Laloumis, D. (2003). Hotel management. Athens: Stamoulis Publications.

Lytras, P. (1999). Tourist psychology and behaviour. (3rd ed.). Athens: Interbooks Publications.

Lytras, P. (2002). Leisure society: holiday's leisure time. (2nd ed.). Athens: Interbooks.

Mikulic, J., \& Prebezac, D. (2011). Evaluating hotel animation programs at Mediterranean sun-and-sea resorts: An impact-asymmetry analysis. Tourism Management, 32(3), 688-696.

Nagle, G. (1999). Tourism, leisure and recreation. Cheltenham (UK): Nelson Thornes.

Sotiriadis, M. (2005). Financial management of hotel operations. Athens: Propobos.

Timothy, D., \& Teye, V. (2009). Tourism and the lodging sector. Oxford: Butterworth-Heinemann.

Torkildson, G. (2004). Leisure and recreation management (5th ed.). London: Routledge.

Weiermair, K., \& Mathies, C. (2004). The tourism and leisure industry: shaping the future. London: Haworth Press.

Yin, K. R. (2003). Case study research: design and methods. (3rd ed.). Thousand Oaks: Sage Publications. 